\title{
The Emergence of E-Commerce Sites and Its Contribution towards the Economic Growth of Bangladesh: A Quantitative Study
}

\author{
Ahmed Imran KABIR, Md. JAKOWAN, Jayeesa BOSU, Md. Sajidul MOHSIN, \\ Rayhan HAMIM \\ School of Business and Economics, United International University, Bangladesh. \\ ahmedimran@bus.uiu.ac.bd, jakowan@bus.uiu.ac.bd, jayeesa7@gmail.com, \\ sajidulmohsin@gmail.com, rhamim163128@bba.uiu.ac.bd
}

This paper aims examine the impact of e-commerce sites on the economic growth in Bangladesh. It also tries to portray the entire scenario of growing e-commerce site and its pros and cons which relates with the national economy. The internet is new window of opportunity for business minded people. E-commerce is anything that contains web enabled transaction. Not only big enterprises but also small and medium enterprises have adopted e-business platform. The scope of e-commerce sites growth is likely to lead to GDP growth and affect the national economic growth. Fruitfulness is stronger in developing country but if government considers e-commerce growth then it's not far away when e-commerce site will be one of the most promising factor that increases National GDP. The result of this study shows that there is a strong positive relationship between all the e-commerce site factors (independent variable) and economic growth (dependent variable) in Bangladesh. Also the result of correlation shows that the relationship among all the independent variables is significant as well.

Keywords: E-Commerce, E-Business, Economic Growth, Government, Bangladesh

DOI: $10.24818 /$ issn14531305/24.3.2020.04

\section{1} Introduction

The term electronic commerce or Ecommerce is related to online transactions. Ecommerce is the form of selling goods and services over the internet. It is one of the most important facets of doing businesses now-adays [1].

Because of the fast internet connection in our country, the e-commerce sector has boomed. In a regular basis, a huge number of transactions occurring as business conduct their operation. What actually e-commerce is? Any economic activity that occurs through computer network can be classified as ecommerce. Currently e- commerce is one of the most growing aspects that influences GDP in Bangladesh. E-commerce is an exciting way of conducting business and selling product/services. Safety concerns are also involved. E-commerce sectors brings much opportunities to the for the business sector as it makes the 24/7 Business possible.

It influences economy positively. It is a very fast growing sector. The sector annual turnover was 1,000 crores in 2016. Around
50,000 people are employed in E- commerce services of Bangladesh. The government must consider that this sector has huge potential. Ecommerce industry will boost the country's economic growth, but first for that this sector should be recognized as a sector that influences national economic growth. Young and educated men who intend to have a business career are much interested in ecommerce. Since the young generation is tech-oriented they are more dedicated towards this sector. This is a very much positive sign that they are interested in business want to create business. The idea of electronic transaction yet need time to gain popularity here. Consumers are yet not comfortable to use their credit card/debit card for online purchasing. They are afraid of getting hacked. New trendy and automated products are currently ruling the business. It is continuously expanding. And other products are increase their trading too. E-commerce business requires high speed internet which is unfortunately absent in rural areas. The cost high too. Operators of mobile phone promises 
3G connection. But in rural area it's hardly accessible. The government should take it as a consideration specially the e-commerce business. It should ensure low - cost and high speed internet for rural people.

In our frame framework we have chosen dependent and independent variable. The independent variables are, Accessibility that tells how easily people can access Ecommerce sites, Electronic Payment refers to web enabled payment, Research \& Development - a factor that is regularly making e-commerce sites better and better., Import Taxation is usually based on the imported goods value, Supply Chain Management is the process of production to consumers, Creating Job Sectors refers to the decrease of unemployment due to ecommerce site. There is only one dependable variable that is economic growth which directly asks what factors economy growth.

The process of our research will be ass follows- we will identify the e-commerce factors contributing to economy growth, review literature and develop framework, collect data through both online and offline survey, analyze the data through SPSS. And doing multiple regression analysis on them to find out the inter relationship between the independent variables and the dependent variable. After that we will interpret the data by accepting or rejecting the hypothesis that will be generated later on.

Positive aspect as an outcome of the research paper-

Answering the question will benefit ecommerce sites customer and the e-commerce site owner along with the government. As the consumer will share their opinion regarding the problems and positive side of e-commerce site. So site owner will make service constant which is liked by the consumer and will try to focus more on services which seems problematic for customer. Government will consider more about e-commerce site as there are many customers who are dedicated purchasing from e-commerce site which in turn increasing GDP.

\section{Literature Review}

\subsection{Accessibility}

Accessibility generally means access. It is the ability for everyone, regardless of any disability or special need, to use, access and benefit from everything within the environment [2].

The websites, tools and technologies of ecommerce should be designed and developed in such way so that each and every people can understand, access and use them. Accessibility of e-commerce supports the inclusion of people with any disability as well as older people and people in rural areas and developing countries to access the websites equally. Accessibility has a stronger business case for e-commerce because those accessible websites have a better search result, increased audience reach and a reduced maintenance cost. It can also enhance the brand, extend market reach and drive the innovation [3].

So, according to Visser and Lanzendorf [4], accessibility for ecommerce's goal is to create the online store that can be used by everybody, regardless of their age, location, skills and presence of any disability.

H1: The factor Accessibility has a positive and significant relationship with the growth of economy in Bangladesh.

\subsection{Electronic Payment}

According to Nwaolisa and Kasie [5], the term e-payment or electronic payment system is the way to conduct transactions or make payment for goods or services by the electronic medium, without using any check or cash. Oyewole, et al. [6] argued that electronic payment system is all-inclusive, representing different aspects of electronic delivery multiple channel.

According to Hord [7], the methods of epayment system includes debit cards, credit cards and $\mathrm{ACH}$ (Automated Clearing House) network. The system of $\mathrm{ACH}$ includes direct deposit, electronic cheque and direct debit. Still in Bangladesh, consumers are unwilling in using electronic payment mode or the system of online payment [8].

Security in payment technologies are very much important for creating trust among 
consumers. Currently, volume of eCommerce transaction in Bangladesh is about TK 1700 Crore per year. But around 90\% eCommerce transactions are done in basis of COD. The online payment amount has to be increased to get the most out of e-Commerce [9].

There is a link between online payment and economic growth. Online payment volume is growing twice in developing economies, faster than it is across the world. Similarly, Non-cash payment system make it quicker and easier for both the people and the businesses to buy goods or services, pump money into the system faster than traditional payment and contribute to GDP [6].

$\mathrm{H} 2$ : The factor Electronic Payment has a positive and significant relationship with the growth of economy in Bangladesh

\section{Research and Development}

Liu, et al. [10] asserted that the process by which companies work to acquire new knowledge that might be used to create new technologies, products or services is known as Research and development (R\&D).

This indicated that all independent variables such as e-commerce, research and development (R\&D), government size, and health expenditure had a long run relationship with the GDP per capita based on the purchasing power parity. This was the

same result obtained by such previous studies as [23] and [24].

Anvari and Norouzi [11] showed that the independent variables such as electronic commerce, government size, research and development and health expenditure had a long run relationship with GDP per capita based on purchasing power parity. R\&D expenditure coefficient was equal to 1.68 , which shows that an increase in $R \& D$ expenditure will lead to 0.0168 percent increase in GDP per capita. Both the ecommerce and the $\mathrm{R} \& \mathrm{D}$ expenditure had a positive impact on GDP per capita.

Anvari and Norouzi [11] recommended that government should pay more attention to economic planning to improve the indicators of e-commerce, so that the government measurements can eventually result in economic development in the country. Bosu, et al. [12] showed that government role can have a positive and significant impact on the growth of e-commerce sites in Bangladesh by providing subsidy and security, creating awareness, developing infrastructure, innovative direction and setting standard.

H3: The factor Research and Development has a positive and significant relationship with the growth of economy in Bangladesh

\subsection{Import Taxation}

Import tax functions as a way for government to raise fund for operations and programs. Import tax or tariff is the financial charge that government usually imposes on goods that are purchased from other country. The primary effect of the import tax is that it makes imported goods relatively more expensive than domestic goods for the domestic consumers. When imported goods are more expensive, the consumers will want to have fewer imported products and likely to demand more domestic products. Exporter's perspective is that import tax is a type of barrier to trade that usually make it difficult to compete with the domestic producers [13].

To a developing country, potential benefit from international e-commerce arises from reduced cost of import as much as from an increased price received for export. Even if any country does not export any service, it can be benefitted from the import of the service, paying for them in terms of goods. Because the availability of medical, architecture and engineering services are low, the longdistance learning and reduced cost of transaction can offer benefits even if the country does not directly export the services traded through the Internet [14].

H4: The factor Import Taxation has a positive and significant relationship with the growth of economy in Bangladesh.

\subsection{Supply Chain Management}

Supply chain management is the process of management of supply chain activities to achieve sustainable competitive advantage and increase customer value. The activities of 
supply chain cover everything from product development, production, sourcing, as well as the needed information system to properly coordinate these activities. It handles the entire production flow of goods or services which starts from raw materials and ends with delivering final products to the customers. Supply chain management is the most important part of many businesses and it boost customer satisfaction and overall company success by reducing operating cost and improving financial position [15].

The internet provides the customers with access to supply and delivery process through creating the customers own personal accounts [16]. So, the journey of e-commerce is not only to set up a website and sell products over online. Rather, it now includes satisfactory infrastructure, product configuration, logistics and of course the supply chain management [17]. E-commerce has accelerated the supply chain process in consideration to the customers' expectations as well as increasing volumes. This new pattern of supply chain that is dealing with brokers and agencies has satisfied the demand of consumers in United States and also brought a huge revenue to the manufacturers of Asia. The e-commerce did not only give the customers more power to compare the prices of the products, but also allowed the companies to find distributors more easily [18].

H5: The factor Supply Chain Management has a positive and significant relationship with the growth of economy in Bangladesh

\subsection{Creating Job Sector}

According to Mandel [19], ecommerce is ultimately a net job creator, not a job destroyer. Their research indicates that ecommerce has created total 400,000 jobs from December 2007 to June 2017, while the traditional retail has lost only 140,000 full time equivalent jobs.

The employment of China driven by ecommerce is shown to exceed 48 million jobs in 2018. These huge employment figures are driven only by the rapid growth of ecommerce industry [20]. According to Vera [21], the rapid growth of E-commerce also has a wider implication in employment, nature of future jobs and economic growth.

According to the projections this paper, ecommerce related revenues in 2005 would account for around 1\% of (nominal) GDP, while contributing up to $8 \%$ of GDP in Philippines. The paper also indicates that this steady increased contribution of e-commerce to GDP growth assumes that e-commerce will play more vital role in future growth of Philippine. Jorgenson, et al. [22] indicate that E-commerce is one of the important determinants in increasing productivity and employment and raising the economic growth rate.

H6: The factor Creating Job Sector has a positive and significant relationship with the growth of economy in Bangladesh

\subsection{Conceptual Framework}

This is our main conceptual framework of the research which shows six independent variables and one dependent variable, Figure 1. 


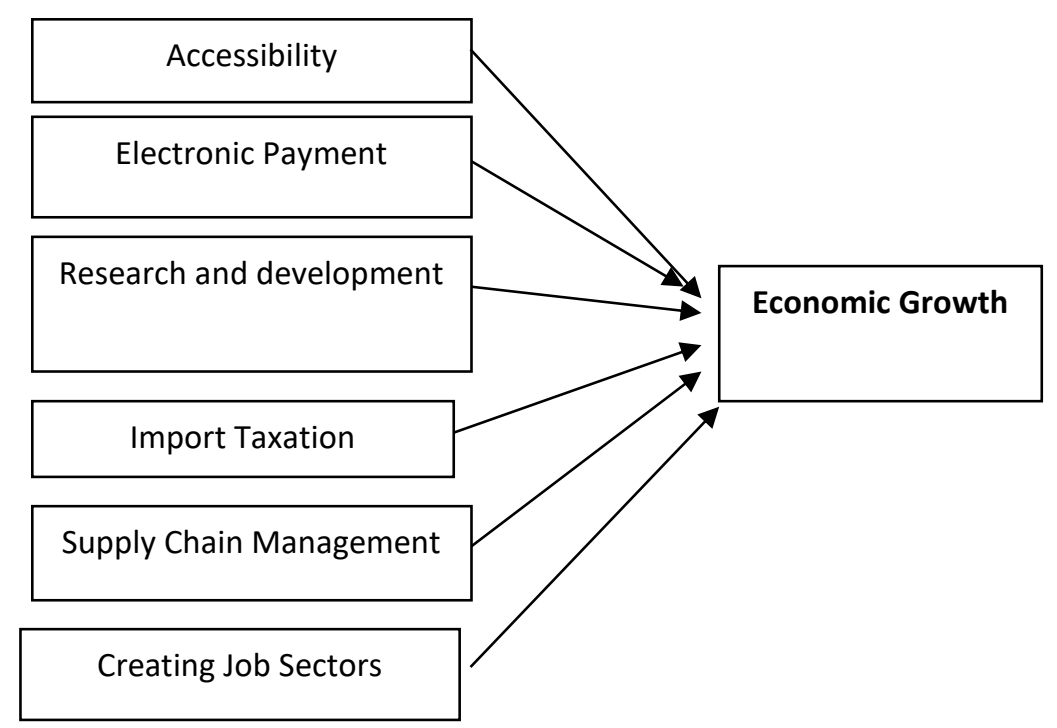

Fig. 1. Variables of the conceptual framework

\section{Research Methodology \\ 4.1 Research Setting}

Research setting is the social and cultural effect of the research on society or business sector. Our research will benefit both the ecommerce sites and the economic sector of Bangladesh. The economists of Bangladesh will know how the e-commerce sites are contributing to the economy and the ecommerce sites will understand hoe they can contribute more. The questions that have been made for the research will let the respondents think that these e-commerce sites are also a factor for those our economy is improving.

\subsection{Research Process}

In this research we are going to find out how e-commerce sites of Bangladesh help national economic growth and for this we are going to recognize the factors of e-commerce sites influencing economic growth in Bangladesh. We found out six independent variables and one dependent variable. Then we reviewed the literature and build a conceptual framework. After that we prepared a questionnaire with 33 questions and collected the data for our research through survey method. We analyzed the data found from the survey using SPSS software. We conducted a reliability test to check the data were reliable or not and then proceed for the regression analysis.

\subsection{Data Collection}

We collected both primary and secondary data for our research. For the primary data, we used survey questionnaire with 33 questions and selected 40 random respondents to fill our questionnaire. We have benchmarked a scale from one to five ( 1 to 5 ) where people gave their response. For secondary data we went through all the necessary secondary sources for gathering a profound knowledge. Related articles, internet, different websites, student papers and textbooks were our main sources of secondary data.

\subsection{Data Analysis}

The data we have collected through survey were tested by the SPSS software. By conducting multiple linear regression, we analyzed the data to find out the desired result. But to make sure that the variables for this research are reliable or not, we needed to go through some reliability test before the regression analysis, Table 1 . We generally measure the Cronbach's alpha value in reliability test. Cronbach's alpha is a coefficient of reliability. The variables are reliable only when the Cronbach's alpha value is greater than 0.7 . Our reliability tale shows that all of the variables got a Cronbach's alpha which is greater than 0.7 except the $R$ and $D$. $\mathrm{R}$ and $\mathrm{D}$ have a value of Cronbach's alpha of .643 which is also close to 0.7 . So it is not a big problem at all. After conducting this 
reliability test we continued for the regression analysis

Table 1. Reliability Test Result (Pilot Test)

\begin{tabular}{|l|l|l|}
\hline Variables & Dimensions & $\begin{array}{l}\text { Cronbach's } \\
\text { Alpha }\end{array}$ \\
\hline Independent & Accessibility & .843 \\
\hline Independent & Electronic Payment & .852 \\
\hline Independent & R and D & .643 \\
\hline Independent & Import Taxation & .717 \\
\hline Independent & Supply Chain Management & .729 \\
\hline Independent & Creating Job Sectors & .840 \\
\hline Dependent & Economic Growth & .814 \\
\hline
\end{tabular}

\subsection{Limitation}

While doing this research, we have faced some difficulties. Some respondent were not able to understand the questions properly and some were not interested to fill the whole questionnaire because there were too many questions for them. Our sample size was not enough for an ideal research. Also, we needed to get some data from the e-commerce sites of Bangladesh such as pickabo, daraz, bagdoom etc. but due to shortage of time and people we could not do it properly.

\subsection{Research Objectives}

The main aim of the research is to examine the key factors of e-commerce sites which may impact the economic growth of Bangladesh. The distinctive objectives of this research are as follows:

1. To examine the relationship between "accessibility" (IV) and "economic growth" (DV) of Bangladesh.

2. To examine the relationship between "electronic payment" (IV) and "economic growth" (DV) of Bangladesh.

3. To examine the relationship between "research and development" (IV) and "economic growth" (DV) of Bangladesh.

4. To examine the relationship between "import taxation" (IV) and "economic growth" (DV) of Bangladesh.
5. To examine the relationship between "supply chain management" (IV) and "economic growth" (DV) of Bangladesh.

6. To examine the relationship between "creating job sectors" (IV) and "economic growth" (DV) of Bangladesh.

\section{Analysis and Result}

This part of research shows the result of the survey by displaying the level of correlation between the six independent variables which are accessibility, electronic payment, research and development, import taxation, creating job sectors and one dependable variable which is economic growth of Bangladesh. We have used quantitative data to do our survey and got the data from survey through a questionnaire with Likert scale for our respondents. The level of scale was from one to five. Here, 1 is equivalent to strongly agree, 2 is equivalent to agree, 3 is equivalent to neutral, 4 is equivalent to disagree, 5 is equivalent to disagree. We were able to do the survey through online and taking invaluable responses from the respondents in our university directly by handing out the questionnaire.

\subsection{Correlation}

Firstly, in correlation table we need to make sure that we don't have multicollinearity 
between our independent variables. Variables are considered as multicollinear if the value of correlation is greater than 0.7 . So the values we have should be less than 0.7 between the independent variables. In Pearson Correlation table, here we can see that most of the values which show the correlation between independent variables are not greater than 0.7, which represents that they are not multicollinear. In addition, the independent variables should correlate with the dependent variable and it will only correlate if the values are greater than 0.3 . In our correlation table, the value of correlation of the economic growth for accessibility is 0.785 , for electronic payment 0.790 , for $\mathrm{R}$ and $\mathrm{D} 0.556$, for import taxation 0.564 , for supply chain management 0.811 and finally for creating job sectors the value is 0.808 . So all of the values are greater than 0.3 and they meet the requirements, Table 2 .

Table 2. Correlations

\begin{tabular}{|c|c|c|c|c|c|c|c|c|}
\hline & & $\begin{array}{l}\text { Economic_gr } \\
\text { owth }\end{array}$ & Accesibility & $\begin{array}{c}\text { Electronic_pa } \\
\text { yment }\end{array}$ & R_and_D & $\underset{n}{\text { Import_taxatio }}$ & $\begin{array}{c}\text { Supply_chain } \\
\text { _manageme } \\
\text { nt }\end{array}$ & $\begin{array}{l}\text { Creating_job } \\
\text { _sectors }\end{array}$ \\
\hline \multirow[t]{7}{*}{ Pearson Correlation } & Economic_growth & 1.000 & .785 & .790 & .556 & .564 & .811 & .808 \\
\hline & Accesibility & .785 & 1.000 & .708 & .520 & .363 & .600 & .554 \\
\hline & Electronic_payment & .790 & .708 & 1.000 & .541 & .516 & .789 & .728 \\
\hline & R_and_D & .556 & .520 & .541 & 1.000 & .463 & .501 & .510 \\
\hline & Import_taxation & .564 & .363 & .516 & .463 & 1.000 & .733 & .643 \\
\hline & $\begin{array}{l}\text { Supply_chain_managem } \\
\text { ent }\end{array}$ & .811 & .600 & .789 & .501 & .733 & 1.000 & .845 \\
\hline & Creating_job_sectors & .808 & .554 & .728 & .510 & .643 & .845 & 1.000 \\
\hline
\end{tabular}

\subsection{Model Summary}

In the model summary table, the value for $\mathrm{R}$ Square is 0.835 and Adjusted R Square is 0.805 . This value of Adjusted R Square says that our model can explain $80.5 \%$ of the variance in the dependent variable, which actually means $0.5 \%$ of the variance can be explained in the economic growth by the ecommerce site factors. This value is absolutely statistically significant. Also, the value of $\mathrm{R}$ Square which is 0.835 is very close to the value of Adjusted R Square that is a very good sign for our research, Table 3 .

Table 3. Model Summary

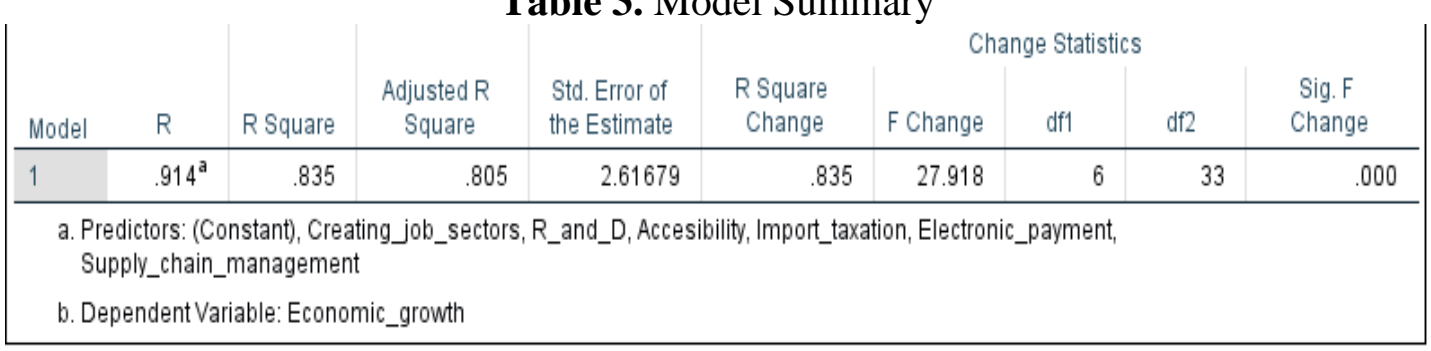

\subsection{ANOVA}

The Table 4 measures that whether the means have a statistically significant difference. Ftest is used here to statistically test the equality of the means. In ANOVA table, the P value or the significance value is 0.00 which is the best level of significance. It means that a significant difference is three between the ecommerce site factors and the economic growth of Bangladesh. 
Table 4. Analysis of Variance in Anova

\begin{tabular}{|c|c|c|c|c|c|c|}
\hline \multicolumn{2}{|c|}{ Model } & Sum of Squares & $\mathrm{df}$ & Mean Square & $\mathrm{F}$ & Sig. \\
\hline \multirow[t]{3}{*}{1} & Regression & 1147.005 & 6 & 191.168 & 27.918 & $.000^{\mathrm{b}}$ \\
\hline & Residual & 225.970 & 33 & 6.848 & & \\
\hline & Total & 1372.975 & 39 & & & \\
\hline
\end{tabular}

a. Dependent Variable:

Economic_growth

b. Predictors: (Constant), Creating_job_sectors, R_and_D, Accesibility, Import_taxation, Electronic_payment, Supply_chain_management

\subsection{Normal P-P Plot}

can see the data are frequently shrouded around the diagonal straight line which means the data are pretty normally distributed. The independent variables are related positively to the dependent variable because most of the data here lies along the best fit line. So the increase in any of the independent variables will also result in the increase in dependent variable.

From our Normal probability plot below we

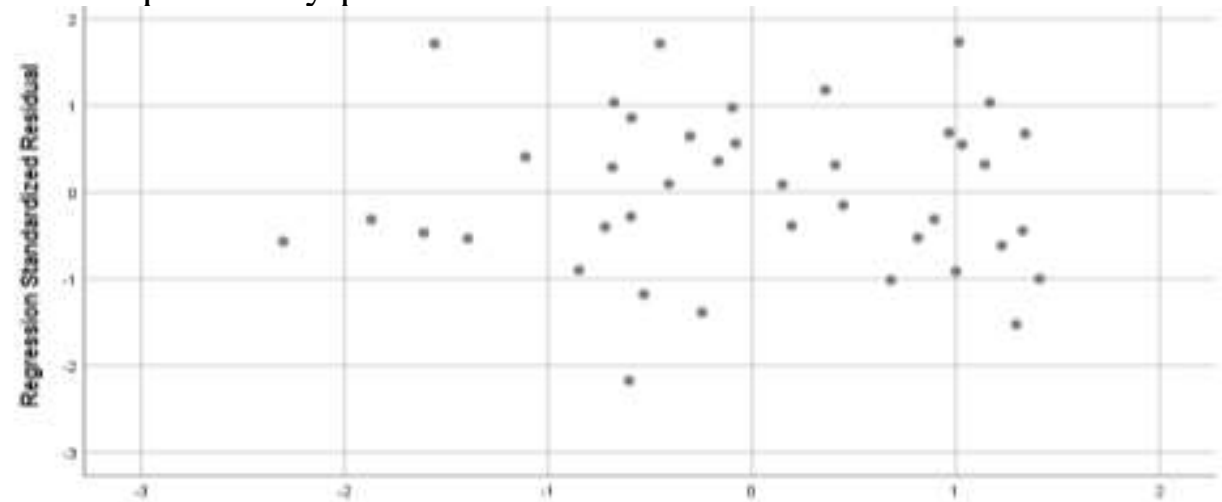

Fig. 2. Regression Standardized Predicted Value

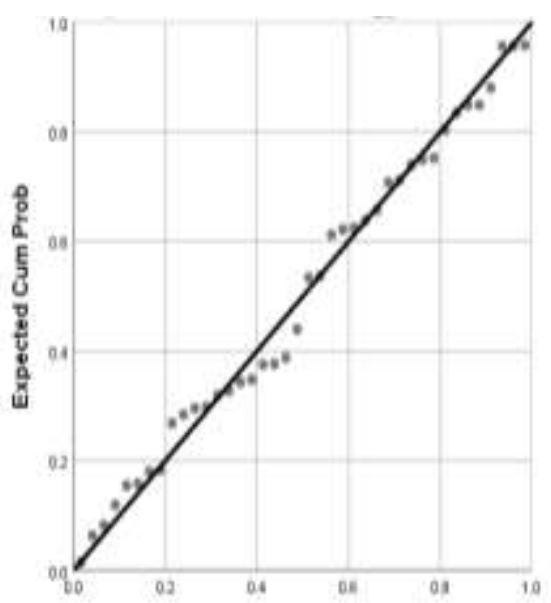

Fig. 3. Observed Cum Prob

\subsection{Scattered Plot}

From the scatterplot, we can observe the data are quite a bit or less scattered with no outliers caught. None of the points should fall outside of -3 to 3 either on $\mathrm{X}$ axis and $\mathrm{Y}$ axis. So, in this case our scattered plot is perfect because no value found that is less than -3 or greater than 3. 


\section{Discussions}

We had to establish six different hypotheses to test the relationship between each of the independent variable and the dependent variable. Whether the hypothesis is accepted or rejected can be examined by the value of Standardized Coefficient Beta. Here the greater value of Standardized Coefficient Beta means the relation is strongly positive between dependent and independent variable. From the table below we can see that among six hypotheses, five hypotheses have been accepted and the other one hypothesis has been rejected. The hypothesis on accessibility, electronic payment, research and development, supply chain management and creating job sectors have been accepted because they have positive Standardized Coefficient Beta value. It means that these five independent variables have a positive relationship with the dependent variable. Here, the accessibility has the strongest positive relationship with its dependent variable. And the hypothesis on import taxation has been rejected because it has a negative Standardized Coefficient Beta value. It means that this particular independent variable has a negative relationship with the dependent variable.

Table 5. Standardized coefficient

\begin{tabular}{ccc}
\hline $\begin{array}{c}\text { Independent } \\
\text { Variables }\end{array}$ & $\begin{array}{c}\text { Standardize } \\
\text { d Coefficient } \\
\text { Beta }\end{array}$ & $\begin{array}{c}\text { Hypothesis } \\
\text { Accepted } \\
\text { /Rejected }\end{array}$ \\
\hline Accessibility & 0.399 & Accepted \\
$\begin{array}{c}\text { Electronic } \\
\text { Payment }\end{array}$ & 0.083 & Accepted \\
$\begin{array}{c}\text { Research and } \\
\text { Development } \\
\text { Import } \\
\text { Taxation }\end{array}$ & 0.030 & Accepted \\
$\begin{array}{c}\text { Supply Chain } \\
\text { Management }\end{array}$ & 0.218 & Accepted \\
Creating Job \\
Sectors
\end{tabular}

\section{Conclusion}

This research was conducted to show the factors of e-commerce sites impact the economic growth in Bangladesh. The six factors of e-commerce sites in this research are accessibility, electronic payment, research and development, supply chain management, import taxation and creating job sectors. And the study proved that these six factors which are independent variables actually positively impact the economic growth, dependent variable of this research. From this research, it is to conclude that increase in any of the six factors of e-commerce sites will result in higher economic growth in Bangladesh. Any further research can be conducted on this topic to fulfill the gap our research has.

\section{References}

[1] M. S. Islam, "E-Commerce in Bangladesh: Growth and Challenges," Journal of Business and Management (IOSR-JBM), vol. 20, pp. 10-15, March 2018.

[2] A. Walden. (2018, August 15). The state of accessibility in e-commerce. Available: https://medium.com/@1snrae/the-state-ofaccessibility-in-e-commercefc97b9bad3a2

[3] T. Maswera, R. Dawson, and J. Edwards, "Analysis of Usability and Accessibility Errors of E-Commerce Websites of Tourist Organisations in Four African Countries," Vienna, 2005, pp. 531-542. 
[4] E. J. Visser and M. Lanzendorf, "Mobility and accessibility effects of B2C ecommerce: a literature review," Tijdschrift voor economische en sociale geografie, vol. 95, pp. 189-205, 2004.

[5] E. F. Nwaolisa and E. G. Kasie, "Electronic retail payment systems: User acceptability and payment problems in Nigeria," Oman Chapter of Arabian Journal of Business and Management Review, vol. 34, pp. 1-18, 2012.

[6] O. S. Oyewole, J. G. El-Maude, M. Abba, and M. E. Onuh, "Electronic payment system and economic growth: a review of transition to cashless economy in Nigeria," International Journal of Scientific Engineering and Technology, vol. 2, pp. 913-18, 2013.

[7] J. Hord. (2019, August 15). How Electronic Payment Works. Available: https://money.howstuffworks.com/person al-finance/online-banking/electronicpayment1.htm, 2019

[8] T. Karim and X. Qi, "E-commerce Development in Bangladesh," International Business Research, vol. 11, p. 201, 10/29 2018.

[9] Fintech. (2018, August 15). E-Commerce And Its Growth In Bangladesh. Available: http://www.fintechbd.com/e-commerceand-its-growth-in-bangladesh/, 2018

[10] T.-K. Liu, J.-R. Chen, C. C. Huang, and C.-H. Yang, "E-commerce, R\&D, and productivity: Firm-level evidence from Taiwan," Information Economics and Policy, vol. 25, pp. 272-283, 2013.

[11] R. D. Anvari and D. Norouzi, "The impact of e-commerce and R\&D on economic development in some selected countries," Procedia-Social and Behavioral Sciences, vol. 229, pp. 354362, 2016.

[12] J. Bosu, B. K. Bhowmick, A. I. Kabir, M. Jakowan, H. A. Happy, S. S. Ahmed, et al., "The Impact of Government Role on the Growth of E-Commerce Sites in Bangladesh," Journal of Asian and African Social Science and Humanities (ISSN 2413-2748), vol. 5, pp. 1-17, 2019.
[13] A. Strzelecki, "Key Features of ETailer Shops in Adaptation to CrossBorder E-Commerce in the EU," Sustainability, vol. 11, p. 1589, 03/15 2019.

[14] N. Terzi, "The impact of e-commerce on international trade and employment," Procedia-Social and Behavioral Sciences, vol. 24, pp. 745-753, 2011.

[15] C. o. S. C. M. P. (CSCMP). (2019, August 15). The Importance of Supply Chain Management. Available: https://cscmp.org/CSCMP/Develop/Starti ng_Your_SCM_Career/Importance_of_S CM/CSCMP/Develop/Starting_Your_Car eer/Importance_of_Supply_Chain_Mana gement.aspx

[16] M. Yang, "Supply Chain Management under E-CommerceEnvironment," International Journal of Innovation, Management and Technology, vol. 3, p. 210, 2012.

[17] J.-M. Nurmilaakso, "Adoption of ebusiness functions and migration from EDI-based to XML-based e-business frameworks in supply chain integration," International Journal of production economics, vol. 113, pp. 721-733, 2008.

[18] R. L.-P. Jorge, "e-Business and the Supply Chain Management," Business Intelligence Journal, pp. 77-89, July 2008.

[19] M. Mandel, "How ecommerce creates jobs and reduces income inequality," Progressive Policy Institute, p. 3, 2017.

[20] ChinaDaily.COM.CN. (2018, August 15). E-commerce in China to create over 48 million jobs in 2018. Available: http://www.chinadaily.com.cn/a/201806/ 08/WS5b19f0b1a31001b82571ee5d.html

[21] R. d. Vera. (2002, August 15). The employment impact of business-toconsumer e-commerce on Philippine workers. Available: https://www.eldis.org/document/A14381

[22] D. W. Jorgenson, M. s. Ho, and K. Stiroh, "Productivity: Information Technology and the American Growth Resurgence," The MIT Press, vol. 3, 2005

[23] P. Hansen, A. King, The determinants of health care expenditure: A cointegration 
approach, Journal of Health Economics, 1996, vol. 15, issue 1, pp. 127-137.
Health Economics, 1997, vol. 16, issue 2, pp. 207-229

[24] A. Blomqvist, R. (Robin) Carter, Is

health care really a luxury?, Journal of

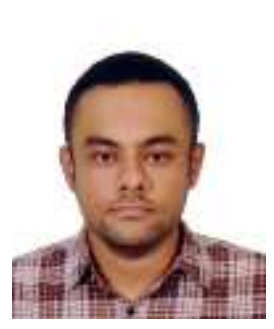

\begin{abstract}
Ahmed Imran KABIR is an experienced Faculty Member in the School of Business and Economics at United International University with working experience in the Management Information Systems and Business Analytics subjects. Strong educational background with a Master of Science in Business Analytics from Texas A\&M University, United States. He has several research papers published in international and national journals and in ISI and Scopus- indexed journals. His objective is to enroll himself in a successful and progressive academic and research organization where he can use his skills and knowledge to improve himself as well as contribute to the goodwill of that organization and make it more efficient. His research interest areas are - Management Information System, Big Data
\end{abstract} Analytics, Blockchain Technology, and Multi-disciplinary studies.

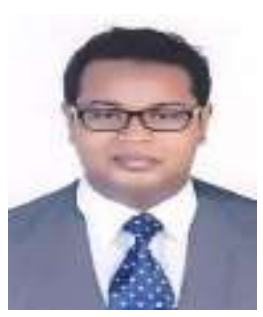

Jakowan is an experienced faculty member with working experience in Human Resource Management and Management courses. Strong educational background with a Master of Business Administration from the University of Dhaka, Bangladesh (Major in HRM) and Bachelor of Business Administration from the same University (Major in Management). He has also achieved professional certification in Supply Chain Management from ISCEA, USA. He is currently working as a faculty member in the School of Business and Economics, United International University, Bangladesh. His passion is to contribute to the realm of teaching and research for the development of his beloved country and the world at large. His research interest areas are - Management, Human Resource Management, Entrepreneurship and Business Plan Development, Green HRM, Employee Engagement, Performance Management System, E-Business and E-Commerce, Supply Chain Management and Multi-disciplinary based on Management and HRM.

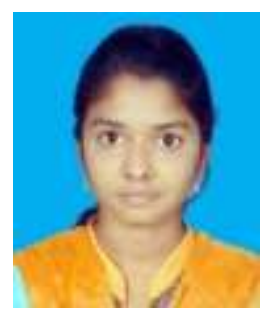

Jayeesa BOSU is currently a student of BBA at United International University, Bangladesh. She is doing double major in Finance and Economics. She has been working in UIU Debate Club as "Program Secretary" and worked as an "Undergraduate Assistant" at her own university besides her study. She also worked for British American Tobacco Bangladesh as a project facilitator named "Your Voice Facilitator" in 2019. One of her research papers on Ecommerce has been published in the Journal of Asian and African Social Science and Humanities in 2019. Her further research interest is on the area of Economics as she wishes to apply abroad for higher study in Economics after completing her BBA.

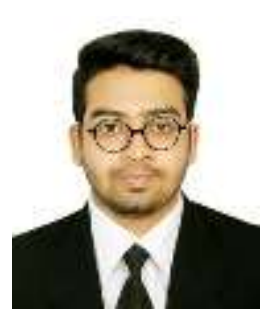

Md. Sajidul MOHSIN is currently a student of BBA at United International University, Dhaka, Bangladesh. His major is finance. He worked at Center for International Affairs and Cooperation - CIAC as a volunteering student. He also worked as Media \& Communication Manager and Brand Manager at UIU Model United Nations - MUN Club and also worked at clubs like at UIU Finance Forum as a general member. He is a skilled volunteer with experience in volunteer works. Familiar with external duties. He has experience working at social works and worked as Correspondent \& Volunteer at Helping Hand Foundation 
Bangladesh. He has some experience as Executive Volunteer at JAGO Foundation. He is highly ambitious with a background in analyzing the circumstantial environment for a task. He has done a research paper on E-commerce and his further field of interest in research is basically finance \& economics.

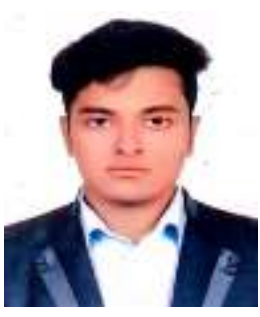

Rayhan HAMIM is currently a student of BBA in United International University, Bangladesh. He is doing major in Finance. He has been working for UIU Finance Forum as an executive member and worked as a volunteer in JAAGO. His further research interest is on corporate finance as he wishes to apply abroad for higher studies in Finance after completing for BBA 


\section{Appendix}

\begin{tabular}{|c|c|c|c|c|c|}
\hline & $\begin{array}{l}\text { S.Disagree } \\
\text { (1) }\end{array}$ & $\begin{array}{l}\text { Disagree } \\
\text { (2) }\end{array}$ & $\begin{array}{c}\text { Neutral } \\
(3)\end{array}$ & $\begin{array}{l}\text { Agree } \\
(4)\end{array}$ & $\begin{array}{l}\text { S.Agree } \\
\text { (5) }\end{array}$ \\
\hline $\begin{array}{l}\text { 1. Wider range of special customer interaction is } \\
\text { increasing in Bangladeshi e-commerce sites }\end{array}$ & & & & & \\
\hline $\begin{array}{l}\text { 2. Old people are buying more goods online } \\
\text { rather than going to physical stores }\end{array}$ & & & & & \\
\hline $\begin{array}{l}\text { 3. Physically disabled people look forward to buy } \\
\text { goods from ecommerce site }\end{array}$ & & & & & \\
\hline $\begin{array}{l}\text { 4. A large number of people who have problems } \\
\text { moving from one place to another can buy } \\
\text { goods easily from anywhere and anytime in } \\
\text { the world even with just a smart phone }\end{array}$ & & & & & \\
\hline $\begin{array}{l}\text { 5. Availability of electronic payment in e- } \\
\text { commerce sites of Bangladesh are influencing } \\
\text { people to make their transaction online which } \\
\text { is increasing GDP }\end{array}$ & & & & & \\
\hline $\begin{array}{l}\text { 6. E-commerce sites like pickaboo.com, } \\
\text { Bagdoom.com gives EMI service on } \\
\text { Electronic Payment which attract a large } \\
\text { customer }\end{array}$ & & & & & \\
\hline $\begin{array}{l}\text { 7. People feel more comfortable buying online } \\
\text { goods using credit cards. }\end{array}$ & & & & & \\
\hline $\begin{array}{l}\text { 8. E-commerce sites of Bangladesh have } \\
\text { secured electronic payment gateway to } \\
\text { increase their sales. }\end{array}$ & & & & & \\
\hline $\begin{array}{l}\text { 9. E-commerce sites use customer data and help } \\
\text { them to get the specific items they search for } \\
\text { by making the items more visible to the } \\
\text { customers }\end{array}$ & & & & & \\
\hline $\begin{array}{l}\text { 10. Electronic shopping cart can increase the sales } \\
\text { by buying goods a lot more easier every time } \\
\text { people visit an e-commerce site }\end{array}$ & & & & & \\
\hline $\begin{array}{l}\text { 11. People usually buy goods from the online } \\
\text { stores which have sufficient information about } \\
\text { the goods they are selling. }\end{array}$ & & & & & \\
\hline $\begin{array}{l}\text { 12. Customers tend to purchase more from } \\
\text { commerce sites which are secured enough }\end{array}$ & & & & & \\
\hline $\begin{array}{l}\text { 13. A lot of imported products are being sold } \\
\text { through these e-commerce sites. }\end{array}$ & & & & & \\
\hline $\begin{array}{l}\text { 14. Customers have a great demand for imported } \\
\text { goods thus e-commerce sites pay a great } \\
\text { amount of import duty for them }\end{array}$ & & & & & \\
\hline $\begin{array}{l}\text { 15. People who love to follow fashion trends look } \\
\text { forward in these e-commerce site for those } \\
\text { goods. }\end{array}$ & & & & & \\
\hline $\begin{array}{l}\text { 16. For heavy duty products such as bikes, cars } \\
\text { etc. are being sold in these sites and these } \\
\text { sites are profiting a lot from them. }\end{array}$ & & & & & \\
\hline $\begin{array}{l}\text { 17. Efficient logistics are grabbing a great number } \\
\text { of customers for great service. }\end{array}$ & & & & & \\
\hline $\begin{array}{l}\text { 18. Bangladeshi e-commerce sites have good } \\
\text { distribution system which is increasing sales. }\end{array}$ & & & & & \\
\hline
\end{tabular}




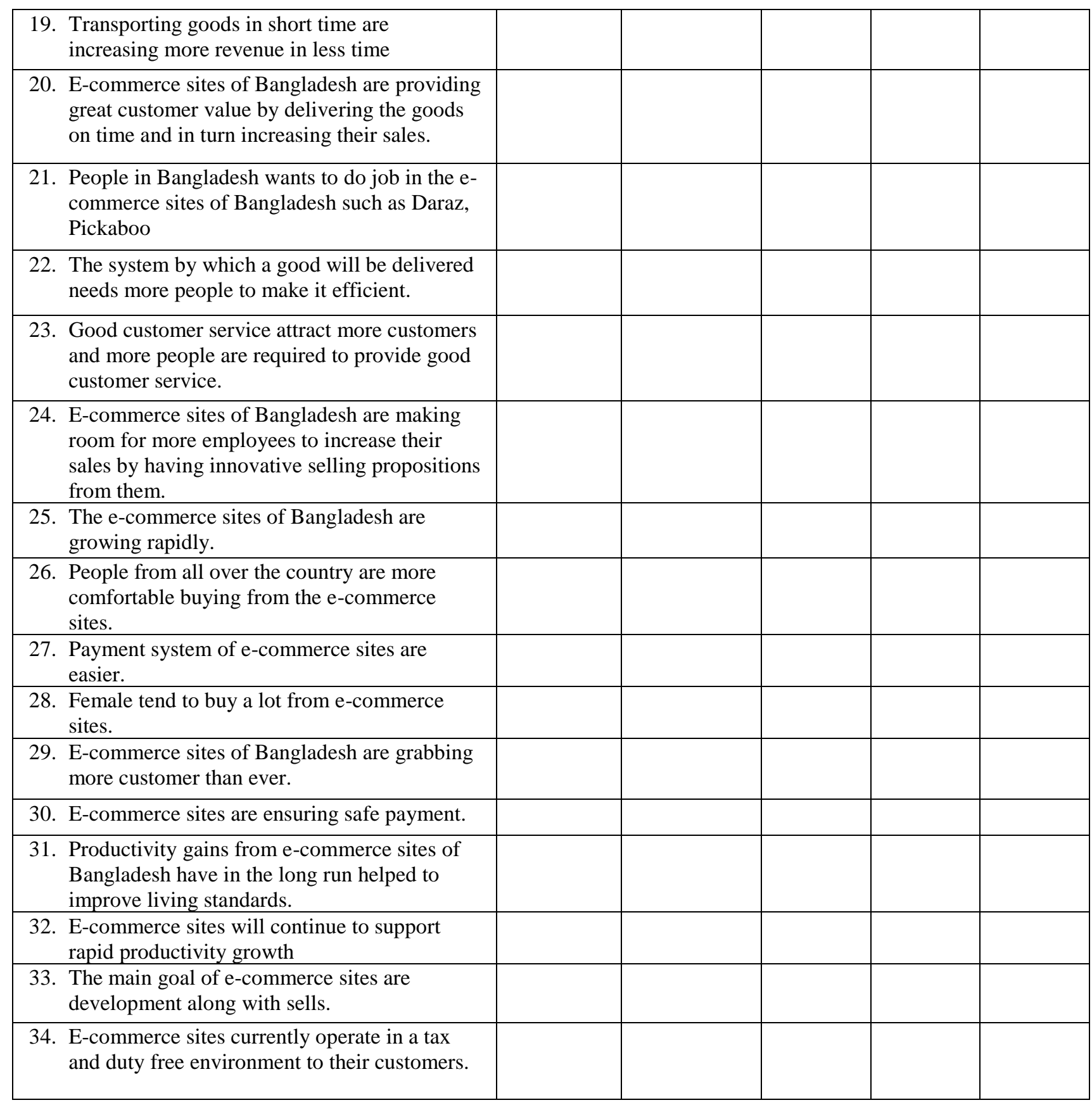

